\title{
ADVERSE HEALTH EFFECTS IN CANADA GEESE (BRANTA CANADENSIS) ASSOCIATED WITH WASTE FROM ZINC AND LEAD MINES IN THE TRI-STATE MINING DISTRICT (KANSAS, OKLAHOMA, AND MISSOURI, USA)
}

\author{
Deon van der Merwe, ${ }^{1,3}$ James W. Carpenter, ${ }^{1}$ Jerome C. Nietfeld, ${ }^{1}$ and John F. Mlesner ${ }^{2}$ \\ ${ }^{1}$ College of Veterinary Medicine, Kansas State University, 1800 Denison Avenue, Manhattan, Kansas 66506, USA \\ ${ }^{2}$ United States Fish and Wildlife Service, Kansas Field Office, 2609 Anderson Avenue, Manhattan, Kansas 66502, USA \\ ${ }^{3}$ Corresponding author (email: dmerwe vet.ksu.edu)
}

1 ABSTRACT: Lead and zine poisoning have been recorded in a variety of bird species, including migrating waterfowl such as Canada Geese (Branta canadensis), at sites contaminated with mine OK as set waste from lead and zinc mines in the Tri-State Mining District, Kansas, Oklahoma, and Missouri, USA. The adverse health impacts from mine waste on these birds may, however, be more extensive than is apparent from incidental reports of clinical disease. To characterize health impacts from mine waste on Canada Geese that do not have observable signs of poisoning, four to eight apparently healthy birds per site were collected from four contaminated sites and an uncontaminated reference site, and examined for physical and physiologic evidence of metals poisoning. Tissue concentrations of silver, aluminum, arsenic, barium, cadmium, cobalt, chromium, copper, iron, magnesium, manganese, molybdenum, nickel, lead, selenium, thallium, vanadium, and zinc were determined by inductively coupled plasma mass spectroscopy. Adverse health effects due to lead were characterized by assessing blood $\delta$-aminolevulinic acid dehydratase (ALAD) enzyme activity. Adverse effects associated with zinc poisoning were determined from histologic examination of pancreas tissues. Elevated tissue lead concentrations and inhibited blood ALAD enzyme activities were consistently found in birds at all contaminated sites. Histopathologic signs of zinc poisoning, including fibrosis and vacuolization, were associated with elevated pancreatic zinc concentrations at one of the study sites. Adverse health effects associated with other analyzed elements, or tissue concentrations indicating potentially toxic exposure levels to these elenents, were not observed.

Key words: Branta canadensis, Canada Goose, lead poisoning, mine waste, Tri-State Mining District, zine poisoning.

\section{INTRODUCTION}

Lead and zinc ores are unevenly distributed in the Tri-State Mining District $6500 \mathrm{~km}^{2} 2$ over a 2,500 square mile area in a southwest to northeast are through northem Ottawa County in Oklahoma, southeast Cherokee County in Kansas, and multiple counties in southwest Missouri, USA (Pope, 2005). Major mining activities in the Tri-State Mining District censed during the 1970s, but hazardous metals, including lead, zine, and cadmium, are still present at high concentrations in mine wastes and stream sediments (Pope, 2005). Lead and zinc poisoning in wild birds has been recorded in the area (Sileo et al., 2003). A survey of wild birds in the Tri-State Mining District in 2001, which included species of waterfowl, upland game birds, and passerines, revealed high tissuc concentrations of lead. There were also physiologic indications of lead exposure in the form of inhibited blood $\delta$ aminolevulinic acid dehydratase (ALAD) activity. Zinc concentrations were elevated in waterfowl tissues, and cadmium concentrations were elevated in songbirds (Beyer et al., 2004). Elevated tissue lead and adverse health effects of lead exposure have been recorded in a variety of other species in the Tri-State Mining District, including fish (Wildhaber et al., 2000), mussels and clams (Mytilidae and Corbiculidae; Angelo et al., 2007), redearcd slider turtles (Trachemys scripta; Hays and McBee, 2007), white-tailed dcer (Odocoileus virginianus; Conder and Lanno, 1999), and midges (Chironomidae; Reynolds and Ferrington, 2002).

The landscape at old mine sites in the Tri-State Mining District is characterized 
by sparsely vegetated soil and mine waste piles as much as $800 \mathrm{~m}$ in diameter. The ground surface in these areas consists of mine and mill wastes including fragmented rock, fine gravel (chat), and tailings of sand and silt (Xiao and Ji, 2007). The region has a generally flat topography, occasionally broken by rivers and streams. Water-filled subsidences have formed over collapsed underground caverns. Acid mine drainage and contaminated groundwater enter crceks close to mine sites (CH2MHILL, 2005). Between mine sites, forested areas are interspersed with other forms of land cover typical of agricultural landscapes, including pasture and crops such as corn, wheat, and soybeans. Some mined areas have been reclaimed for residential and industrial use (Murgueytio et al., 1996). Most mine waste surface drainage flows into the Spring River, which meanders southwesterly through the central region of the Tri-State Mining District and merges with the Neosho River in central Ottawa County, Oklahoma. Smaller streams draining mine sites flow directly into the Neosho River in northern Ottawa County. Habitat elements that attract Canada Geese (Branta canadensis) are present in the Tri-State Mining District, including shelter, open water, and food sources. Canada Geese tolerate human activity and often occur in suburban and agricultural environments (Conover and Chasko, 1985).

Canada Geese experimentally exposed to toxic concentrations of lead in the form of lead shot pellets exhibit a poor correlation between the exposure and the appearance of overt clinical signs (Cook and Trainer, 1966). We hypothesized that although credible evidence for the occurrence of lead and zinc poisoning in Canada Geese in the Tri-State Mining District is available, the true extent of adverse health impacts are not apparent from reports of clinical poisoning. To test this hypothesis, we collected Canada Geese with no obvious signs of ill health associated with lead or zinc poisoning, such as abnormal movement or behavior or loss of body condition, at mine wastecontaminated sites and at a reference site to assess the presence of preclinical lesions, metals accumulation in tissues, and physiologic markers of adverse health effects associated with metals exposure.

\section{MATERIALS AND METHODS}

\section{Sample collection}

From 2 June 2009 to 4 June 2009, birds were collected by US Fish and Wildlife Service personnel under permits from the US Fish and Wildlife Service, the Kansas Department of Wildlife and Parks, the Missouri Department of Conservation, and the Oklahoma Department of Wildlife Conservation. Most birds were collected by shooting with a shotgun using steel shot, while birds at the reference site (hereafter referred to as CON) were collected by entrapment in a temporary enclosure. No birds displayed obvious signs of lead or zinc poisoning, such as abnormal movement or behavior, or loss of body condition. At this time of year, Canada Geese that hatched in the spring are preflight juveniles. Although we targeted preflight juveniles, the birds' tight flocking behavior resulted in the capture of some adults. Based on the protective behavior of the adult birds toward the preflight juveniles, the adult birds were presumed to be members of the rearing groups of the preflight juvenile birds. Four to eight birds per site were collected at four mine waste-contaminated sites and at a reference site outside the Tri-State Mining District that does not receive drainage from contaminated areas. The locations of the contaminated sites (Fig. 1) were as follows: three juveniles and two adults were collected from a subsidence pond surrounded by sparsely vegetated mine chat $\left(37^{\circ} 9^{\prime} 36.36^{\prime \prime} \mathrm{N}, 9^{\circ} 27^{\prime} 28.08^{\prime \prime} \mathrm{W}\right)$, in a northern suburb of Webb City, Missouri, hereafter referred to as MO; five juveniles were collected from a farm pond next to a mine waste pile $\left(36^{\circ} 59^{\prime} 15.00^{\prime \prime} \mathrm{N}, 94^{\circ} 51^{\prime} 12.96^{\prime \prime} \mathrm{W}\right)$, $2 \mathrm{~km}$ west of Picher, Oklahoma, hereafter referred to as OK; six juveniles and two adults were collected from the confluence between the Spring River and Short Creek where mine waste was deposited in the streambed of Spring Creek $\left(37^{\circ} 5^{\prime} 36.96^{\prime \prime} \mathrm{N}, 9^{\circ} 40^{\prime} 57^{\prime \prime} \mathrm{W}\right), 4.2 \mathrm{~km}$ northwest of Galena, Kansas, hereafter referred to as KSE; and three juveniles and one adult were collected from the northern bank of Shoal Creek $\left(37^{\circ} 2^{\prime} 32.28^{\prime \prime} \mathrm{N}, 94^{\circ} 40^{\prime} 45.84^{\prime \prime} \mathrm{W}\right)$ in an area without visible mine waste that receives 


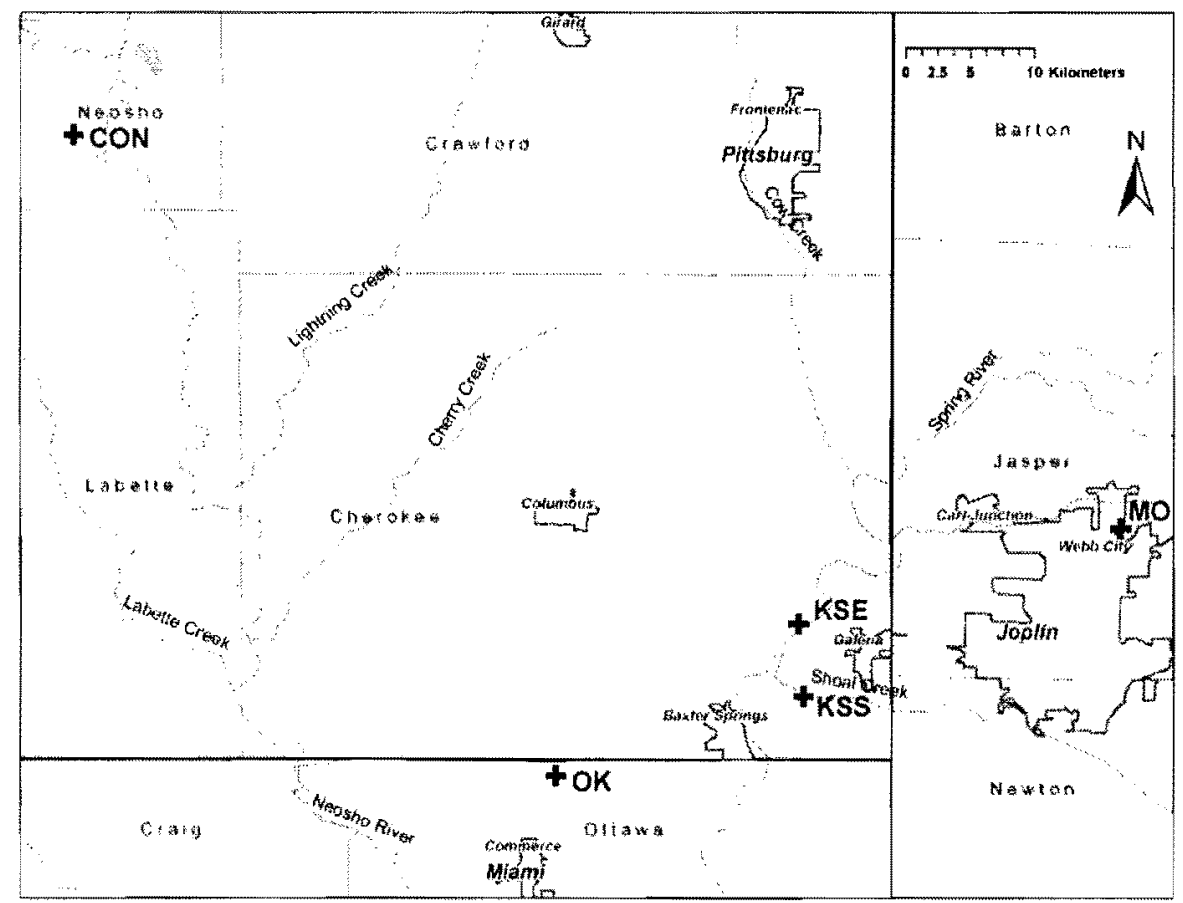

Ficure 1. Study region showing Canada Geese (Branta canadensis) collection sites for determining lead-

These are site ID codes, not abbieviutions.

drainage from mine waste, $5.1 \mathrm{~km}$ southwest of Galena, Kansas, hereafter referred to as KSS. Six juveniles were collected from the reference site (CON), which was situated at a farm pond $\left(37^{\circ} 26^{\prime} 13.20^{\prime \prime} \mathrm{N}, 95^{\circ} 11^{\prime} 26.16^{\prime \prime} \mathrm{W}\right) 1.6 \mathrm{~km}$ north east of Neosho State Fishing Lake, Kansas.

Birds captured alive were humanely euthanized by an overdose of the anesthetic gas isoflurane delivered via a facemask. Ages were estimated using guidelines developed for use in this species based on emergence, distribution, length, and color characteristics of down and feathers (Yocom and Harris, 1965). The midpoints of 7 -day intervals were used when plumage development matched descriptions and were adjusted toward interval boundaries when plumage development was intermediate Birds were weighed, and blood samples were collected shortly after capture from the jugular vein, the basilic vein, or the medial metatarsal vein using heparinized $3-\mathrm{ml}$ syringes and 25 -

Corret 4 gauge needlcs. A $0.5-\mathrm{ml}$ volume of each sample was placed into a $2-\mathrm{ml}$ cryogenic vial (Fisherbrand, Fisher Scientific, Pittsburgh Pennsylvania, USA), flash-frozen in liquid nitrogen $(-196 \mathrm{C})$, and placed in an ultralow freezer $(-80 \mathrm{C})$. Samples were shipped overnight on dry-ice $(-78.5 \mathrm{C})$ to the Division of Comparative Pathology, Miller School of Medicine, University of Miami, Miami, Florida, USA, for ALAD analysis. The remaining blood from each sample was placed into a trace element blood collection tube (BD Vacutainer, BD, Franklin Lakes, New York, USA) for assays of packed cell volume (PCV) and element concentrations. The PCVs were measured in duplicate by the microhematocrit method using a microcapillary centrifuge at $5,000 \times \mathrm{G}$ for $5 \mathrm{~min}$. The average $\mathrm{PCV}$ for each bird was then determined. No PCVs were obtained for some birds because the blood clotted prior to centrifugation.

Birds were necropsied following the procedure outlined in the Avian Disease Manual (Charlton et al., 2000). Their body condition and any macroscopic lesions were recorded. Samples of trachea, lungs, heart, pancreas, liver, spleen, kidney, adrenal glands, gonads, breast muscle, brain, bone marrow, and bursa of Fabricius were collectcd, regardless of the presence or absence of lesions, and fixed in $10 \%$ neutral-buffered formalin. Formalinfixed tissues were routinely processed, embedded in paraffin, sectioned at $3 \mu \mathrm{m}$, mounted on glass slides, and stained with hematoxylin and eosin at the Kansas State Veterinary 
Diagnostic Laboratory, Kansas State University, Manlattan, Kansas. The slides were examined by one pathologist and any abnormal findings were recorded. Samples for element analysis of brain, liver, kidney, pancreas, skeletal muscles, and a long bone (femur or metatarsus) were collected individually in digestion cups (SC475, Environmental Express, Mt. Pleasant, South Carolina, USA), without the addition of preservatives.

\section{Sample analysis}

Blood ALAD activity was measured according to an established method (Burch and Siegel, 1971). A unit of ALAD activity was defined as an increase in corrected absorbance at $555 \mathrm{~nm}$ of 0.100 per hour, with a $1.0-\mathrm{cm}$ light path length and $1-\mathrm{ml}$ red blood cell

5. volume, at $38 \mathrm{C}$. Activity was normalized for each sample's PCV. A duplicate KSE3 blood sample was analyzed for quality control and generated similar results to the first sample. Since there was no significant difference between the PCVs of any groups based on Kruskal-Wallis one-way analysis of variance on ranks, ALAD activity for samples without measured PCV values was estimnted using the mean PCV value from the respective site. One sample was severely clotted and could not be analyzed (KSS1).

Tissue samples for element analyses were processed at the Kansas State Veterinary Diagnostic Laboratory. Samples were digested in nitric acid, and analyzed on a wet wcight basis. One gram of sample $(1 \mathrm{ml}$ for blood) was mixed in a digestion cup (SC475, Environmental Express) with $3 \mathrm{ml}$ of ultrapure water (Milli-Q Biocel, Millipore, Bedford, Massachusetts, USA) and $4 \mathrm{ml}$ of $70 \%$ nitric acid (TraceMetal Grade, Fisher Scientific), capped and heated (HotBlock ${ }^{\mathrm{TM}}$, Environmental Express) at $105 \mathrm{C}$ for $3 \mathrm{hr}$, then diluted with $18 \mathrm{ml}$ of water. Samples that contained visible particulates after digestion were filtered using $2-\mu \mathrm{m}$ filters (Filtermate ${ }^{\mathrm{TM}}$, Envirommental Express). Prepared samples were analyzed by inductively coupled plasma mass spectroseopy (ICP-MS; Agilent ICP-MS $7500 \mathrm{cx}$, Agilent Technologies, Wilnington, Delaware, USA) for a panel of elements including magnesium, aluminum, vanadium, chromium, manganese, iron, cobalt, nickel, copper, zinc, arsenic, selenium, nolybdenum, silver, cadmium, barium, thallium, and lead. Hydrogen reaction and helium collision were used for interference removal and an argon dilution system was used to extend the range of acceptable total dissolved solids concentrations up to $1 \%$. Standards for element analyses by ICP-MS were obtained from Envirommental Express. To account for sample matrix effects, scandium, rhodium, indium, lutetium, and bismuth were used as fixed concentration internal standards and quantitation was achieved by measurements of the ratios between internal standards and the elements of interest. Limits of quantitation varied by matrix because of different dilution requirements and were defined as the lowest quantifiable standard multiplied by the sample dilution factor. Reference samples containing element concentrations of $1 \mathrm{mg} /$, prepared from commercially available standards (Envirommental Express), were used for data quality assurance. Acceptable quality was defined as a measured concentration between 0.8 and 1.2 times the actual concentration. Each batch of samples included digestion or processing blanks. Element concentrations in blanks were used to correct results for background contaminants.

\section{Statistical analyses}

Statistical analyses were performed in SigmaPlot Version 11.2, Build 11.2.0.5 (Systat Software Inc., Chicago, Illinois, USA). Statistical significance was set at alpha $=0.05$. Multiple group comparisons by one-way analysis of variance were performed on data that passed normality tests. Kruskal-Wallis one-way analysis of variance on ranks was used on data that failed normality tests. Lead in liver, brain, and muscle was excluded from these analyses because lead concentrations in the reference samples were below the limit of detection and variability could therefore not be estimated. Where group differences were significant $(P<0.05)$, multiple comparisons were performed using Dumnett's method for normally distributed data, or Dunn's method for data that were not normally distributed. The statistical analyses were repeated on preflight juveniles ouly, Pearson product moment correlation tests were performed to identify and characterize correlations.

\section{RESULTS}

Necropsies revealed no significant gross pathology. All birds were in good body condition with normal muscling and adequate subcutaneous and intemal body fat. There were no consistent differences in microscopic lesions between juvenile and adult birds. The most common histologic changes in organs other than the pancreas were associated with parasitism. Parasit- 


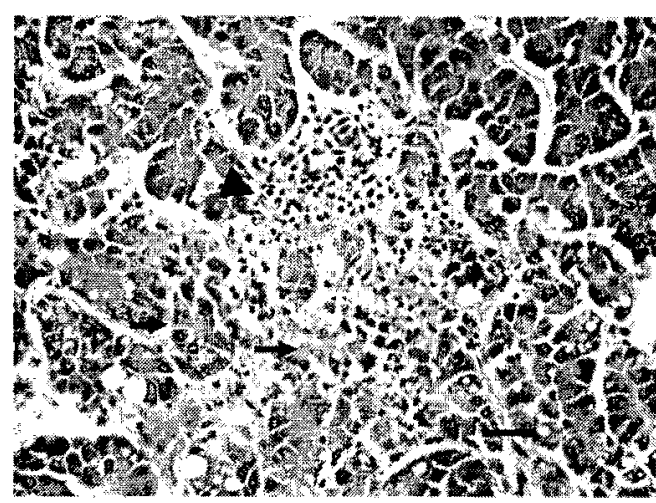

Figure 2. Photomicrograph of the pancreas from a Canacla Goose (Branta canadensis) collected at at mine waste contaminated site in the Tri-State Mining District during June 2009 (Kansas, Oklahoma, and Missonri, USA), showing lesions associated with zinc poisoning, induding vacnolation of exocrine epithelial cells, small epithelial cells that lack or have decreased zymogen granules (arrows), and scattercd small groups of pyknotic cells (arrowhead). The bur indieates $100 \mu \mathrm{m}$.

ism was present in mine waste-exposed birds and reference birds in an apparently random pattern. There was some differentiation between parasitism in juveniles and adults. Viable and mineralized trematode ova, surrounded by granulomatous inflammation, were present in the mucosal, submucosal, and muscular layers, and occasionally on the serosa, of the large intestine of five juveniles. The kidneys of 14 juveniles had multifocal tubulointerstitial inflammation associated with developing stages of coccidia. Two species of nematodes were observed in the wall of the ventriculus of three geese.

Multifocal degenerative changes were present in the pancreas of five of eight birds (three juveniles and two adults) from the KSE site (Figs, 2 and 3). In affected areas, pancreatic exocrine cells were disorganized and smaller than normal with variably sized, clear cytoplasmic vacuoles and decreased quantities of zymogen gramules. There were individual and small groups of shrunken, eosinophilic cells with pyknotic nuclei. The cellular degeneration was accompanied by interstitial fibrosis in

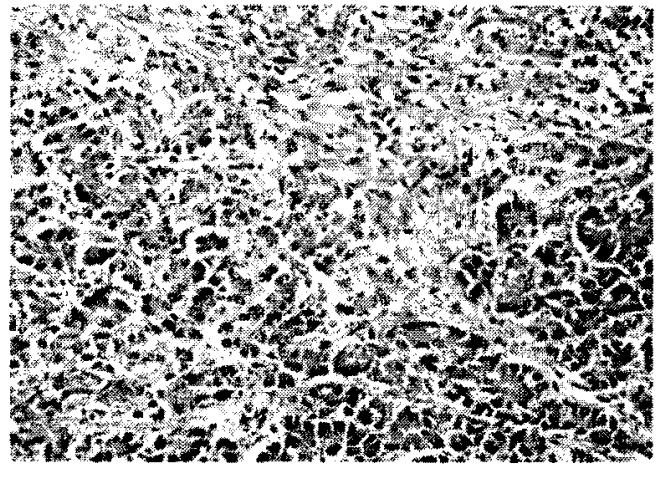

Figune 3. Photomicrograph of the pancreas from a Canada Goose (Brantu canadensis) collected at a mine waste-contaminated site in the Tri-State Mining District during June 2009 (Kansas, Oklahoma, and Missouri, USA), showing lesions associated with zine poisoning, including an area of interstitial fibrosis with loss of exocrine glands.

one juvenile and one adult. The degenerative changes occurred as large coalescing areas in two juveniles and one adult, and were lightly scattered throughout the pancreas of one juvenile and one adult.

Bird weights averaged $2.1 \mathrm{~kg}$ (median $2.29 \mathrm{~kg}$, range $0.95-3.23 \mathrm{~kg}$, SE $0.134 \mathrm{~kg}$ ) for juveniles and $4.36 \mathrm{~kg}$ (median $4.38 \mathrm{~kg}$, range $3.75-4.75 \mathrm{~kg}$, SE $0.179 \mathrm{~kg}$ ) for adults. Juvenile bird ages averaged 38 days (median 41 days, range $21-47$ days, SE 1.54 days). Packed cell volumes of mine waste-exposed birds averaged $36.7 \%$ (median $36.7 \%$, range $25.0-48.7 \%$, SE $1.39 \%$ ) and were significantly lower than reference PCVs $(P=0.046)$, which averaged $41.5 \%$ (median $41.6 \%$, range $39.4-43.1 \%$, SE $0.588 \%$ ). Blood ALAD activities of mine waste-exposed birds averaged 6.1 units (median 6.0, range 0.1-14.7, SE 1.03) and were significantly lower than reference blood ALAD activities $(P<0.001)$, which averaged 30.1 units (median 28.6, range 22.8-40.6, SE 2,82). Blood ALAD inhibition at the mine waste sites, expressed as a percentage derived from the equation: (reference average population average) $\times 100$, was $97.1 \%$ (SE $0.8 \%$ ) at the $\mathrm{MO}$ site, $78.2 \%$ (SE $2.1 \%$ ) at the OK site, $70.7 \%$ (SE $5.8 \%$ ) at the KSE 


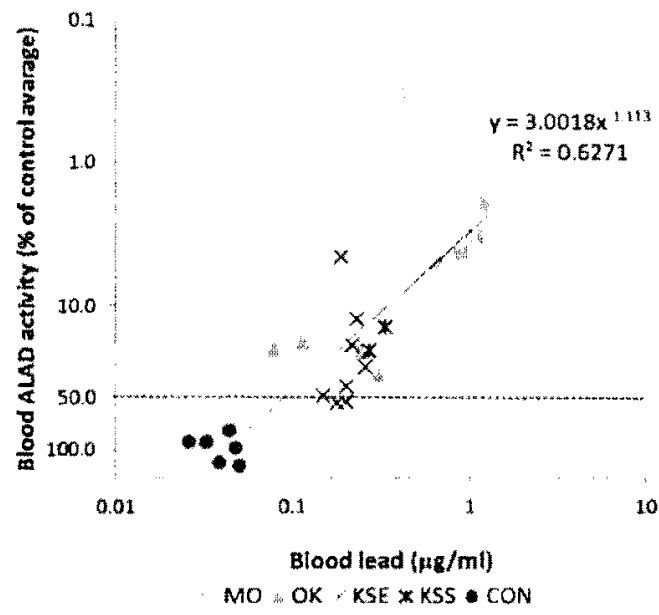

Figure 4. Relationship between blood 8-aminolevulinic acid dehydratase ( $A L A D$ ) enzyme activity and blood lead concentrations in Canada Geese (Branta canadensis) collected at a mine wastecontaminated sites in the Tri-State Mining District during June 2009 (Kansas, Oklahoma, and Missouri, USA).

site, and $82.9 \%$ (SE $3.2 \%$ ) at the KSS site. Blood ALAD inhibition was not correlated with age in juvenile birds $(R=-0.0683$; $P=0.809$ ). Blood ALAD inhibition in preflight juveniles (excluding adult birds) at the mine waste sites was $97.2 \%$ (SE $1.3 \%$ ) at the MO site, $78.2 \%$ (SE $2.1 \%$ ) at the OK site, $66.1 \%$ (SE 6.7\%) at the KSE site, and $79.7 \%(n=1)$ at the KSS site. The pattern of ALAD inhibition remained the same whether adults were included or excluded. Blood ALAD activities were inversely correlated with tissue lead concentrations in all tissues except muscle. The quantitative relationship between blood lead and ALAD activity, derived using all birds, could be mathematically modeled using a power equation with an $R^{2}$ of $0.627: y=3.0018 x^{-1.113}$, where $y$ is the ALAD activity expressed as a percentage of the average reference activity, and $x$ is the blood lead concentration in micrograms per milliliters (Fig. 4).

Although various elements, including cadmium, chromium, silver, nickel, aluminum, arsenic, thallium, cobalt, molybdenum, and vanadium were elevated at one or more contaminated sites compared to the reference site (data not shown), these elements were not associated with tissue concentrations known to be associated with toxicity in birds (Puls, 1994). The analysis, therefore, was focused on lead and zinc. The limits of detection for lead and zinc were $0.024 \mathrm{mg} / \mathrm{kg}$ and $0.121 \mathrm{mg} /$ $\mathrm{kg}$, respectively, while the limits of quantification for lead and zine were $0.079 \mathrm{mg} /$ $\mathrm{kg}$ and $0.402 \mathrm{mg} / \mathrm{kg}$, respectively. Limits of detection and quantification values were the same in blood, but with units in micrograms per milliliters. Lead and zine tissue concentrations are presented in Table 1, and the statistical significance of differences between site means, compared with the reference site birds, are summarized in Table 2. Lead concentrations were consistently elevated in tissues from contaminated sites compared with the reference site. Although statistical significance tests could not be performed in liver, brain, and muscle because the lead concentrations in the reference samples were below the limit of detection, lead concentrations in liver and brain samples from mine waste sites were one to two orders of magnitude higher than the limit of detection, which indicates substantial lead accumulation in these tissues compared to the references. Lack of statistical significance of tissue lead concentration elevations at the KSS site compared to the reference site should be interpreted with caution because the power of statistical tests to resolve differences between groups was limited by relatively low sample numbers at the KSS site $(n=4)$. Blood lead concentrations were not correlated with PCVs $(R=-0.0165 ; P=0.943)$. There was significant covariance between lead concentrations in tissues, with the exception of muscle. These covariance patterns remained similar when adults were excluded from the analysis. Pancreas lead concentrations from the KSE site ranked second highest among the four exposure sites, while they ranked third highest in most other tissues. This anomaly occurred in 
TABLE 1. Tissue lead and zinc concentrations $( \pm S F$ ) in Canada geese (Branta canadensis) collected at four mine waste-contaminated sites (see Fig. 1) designated MO $(n=5)$, OK $(n=5), \operatorname{KSE}(n=8), \mathrm{KSS}(n=4)$, and an uncontaminated reference site, CON $(n=6)$. Units are milligrams per kilogram in all tissues except blood (micrograms per milliliter). Limits of deteetion for lead and zine were $0.024 \mathrm{mg} / \mathrm{kg}(\mu \mathrm{g} / \mathrm{ml}$ in blood) and $0.121 \mathrm{mg} / \mathrm{kg}$ ( $\mu \mathrm{g} / \mathrm{ml} \mathrm{in} \mathrm{blood),} \mathrm{respectively.}$

6

\begin{tabular}{|c|c|c|c|c|c|c|c|c|}
\hline \multirow[b]{2}{*}{ Site ${ }^{i x}$} & \multicolumn{8}{|c|}{ Tissue type } \\
\hline & Liver & Kidney & Pancreas & Brain & Blood & Muscle & Bone: & $\begin{array}{l}\text { Proventriculus } \\
\text { contents }\end{array}$ \\
\hline \multicolumn{9}{|l|}{ Lead } \\
\hline MO & $1.72 \pm 0.13$ & $7.03 \pm 0.26$ & $4.08 \pm 0.35$ & $0.55 \pm 0.03$ & $0.86 \pm(0.06)$ & $0.16 \pm(0.16)$ & $72.86 \pm(6.97)$ & $8.04 \pm 0.51$ \\
\hline OK & $0.38 \pm 0.01$ & $1.41 \pm 0.04$ & $0.87 \pm 0.04$ & $0.19 \pm 0.01$ & $0.20 \pm 0.02$ & $0.03 \pm 0.00$ & $29.71 \pm 0.49$ & $43.98 \pm 2.14$ \\
\hline KSE & $0.33 \pm 0.03$ & $1.18 \pm 0.09$ & $1.23 \pm 0.12$ & $0.22 \pm 0.03$ & $0.20 \pm 0.00$ & $\mathrm{BD}$ & $23.48 \pm 1.28$ & $52.90 \pm 2.18$ \\
\hline KSS & $0.67 \pm 0.11$ & $1.98 \pm 0.15$ & $1.00 \pm 0.13$ & $0.21 \pm 0.04$ & $0.40 \pm 0.04$ & $B D$ & $28.62 \pm 1.98$ & $11.92 \pm 2.04$ \\
\hline $\mathrm{CON}$ & $\mathrm{BD}$ & $0.20 \pm 0.05$ & $0.04 \pm 0.00$ & $\mathrm{BD}$ & $0.04 \pm 0.00$ & BD & $0.88 \pm 0.07$ & ND \\
\hline \multicolumn{9}{|l|}{ Zinc } \\
\hline MO & $52.10 \pm 5.00$ & $26.26 \pm 1.92$ & $38.48 \pm 2.49$ & $10.06 \pm 0.13$ & $7.02 \pm 0.13$ & $15.46 \pm 1.66$ & $281.08 \pm 37.16$ & $316.95 \pm 39.21$ \\
\hline OK & $83.26 \pm 3.24$ & $22.82 \pm 0.51$ & $42.68 \pm 0.96$ & $9.32 \pm 0.11$ & $9.84 \pm 1.38$ & $15.52 \pm 1.29$ & $338.30 \pm 4.89$ & $251.32 \pm 7.20$ \\
\hline KSE & $178.44 \pm 5.50$ & $48.66 \pm 2.29$ & $212.49 \pm 8.66$ & $12.66 \pm 0.59$ & $6.48 \pm 0.09$ & $13.09 \pm 0.30$ & $451.41 \pm 18.28$ & $327.23 \pm 17.2$ \\
\hline KSS & $95.05 \pm 7.43$ & $26.20 \pm 0.24$ & $68.88 \pm 10.70$ & $9.95 \pm 0.13$ & $11.17 \pm 2.13$ & $17.90 \pm 1.42$ & $268.83 \pm 12.71$ & $152.00 \pm 7.23$ \\
\hline CON & $68.00 \pm 0.95$ & $25.22 \pm 0.50$ & $37.20 \pm 0.31$ & $9.85 \pm 0.07$ & $6.53 \pm 0.14$ & $13.62 \pm 0.45$ & $134.69 \pm 2.43$ & ND \\
\hline
\end{tabular}

${ }^{2} \mathrm{MO}$; OK; KSE; KSS; CON

${ }^{b} \mathrm{BD}=$ below detection limit; $\mathrm{ND}=$ no data. 
TABLE 2. Statistical significance of multiple comparisons of differences between lead and zine concentrations in bird tissues from folr mine waste-exposed sites (see Fig. 1) compared with a reference site. Includes all birds and preflight juveniles, at a confidence level of $95 \%$. "+" = significantly different from reference site; "-" = not significantly different.

\begin{tabular}{|c|c|c|c|c|c|c|c|}
\hline Site & Liver & Kidney ${ }^{\text {Al }}$ & Pancreas ${ }^{\text {al } 2}$ & Brain & Blood $^{\mathrm{B}}$ & Muscle & Bone $^{\text {lhs }}$ \\
\hline \multicolumn{8}{|c|}{ Lead (all birds) } \\
\hline MO & No test & + & + & No test & $+t^{b}$ & No test & + \\
\hline OK & No test & - & - & No test & $-b$ & No test & + \\
\hline KSE & No test & - & + & No test & $-{ }^{b}$ & No test & - \\
\hline KSS & No test & - & - & No test & $-^{\mathrm{b}}$ & No test & - \\
\hline \multicolumn{8}{|c|}{ Zinc (all birds) } \\
\hline MO & -cel & - & - & $-{ }^{a}$ & - & $-c$ & - \\
\hline OK & $-c d$ & - & - & $-\mathrm{a}$ & - & $-^{c}$ & + \\
\hline KSE & $++^{\mathrm{Cll}}$ & + & + & $-{ }^{\mathrm{a}}$ & - & $-c$ & + \\
\hline KSS & $-^{\mathrm{cd}}$ & - & - & $-i$ & - & $-c$ & - \\
\hline \multicolumn{8}{|c|}{ Lead (juveniles) } \\
\hline $\mathrm{MO}$ & No test & + & + & No test & $+b$ & No test & + \\
\hline OK & No test & + & - & No test & $-{ }^{b}$ & No test & + \\
\hline KSE & No test & - & + & No test & $-{ }^{b}$ & No test & - \\
\hline KSS & No test & - & - & No test & $-\mathrm{b}$ & No test & - \\
\hline \multicolumn{8}{|c|}{ Zinc (juveniles) } \\
\hline MO & $-c d$ & $-e$ & - & $-{ }^{H}$ & - & $-c$ & - \\
\hline OK & $-\mathrm{cd}$ & $-{ }^{e}$ & - & $-:$ & - & $-{ }^{c}$ & - \\
\hline KSE & $+t^{\mathrm{ed}}$ & $-{ }^{e}$ & + & $-{ }^{i a}$ & - & $-c$ & + \\
\hline KSS & $-c d$ & $-^{e}$ & - & $-a$ & - & $-c$ & - \\
\hline
\end{tabular}

"Kruskal-Wallis one-way analysis of variance on ranks.

b Multiple comparisons versus reference group (Dunn's method).

- Paranetric one way analysis of variance.

d Multiple comparisons versus reference group (Dunnett's method).

e Difference greater than expected by chance using Kruskal-Wallis one-way analysis of variance on ranks, but the group(s) is (are) not identifiable by Dnnn's method.

association with high zinc concentrations and zinc-associated pancreatic lesions at the KSE site. Zinc concentrations were elevated in pancreas, liver, and bone from the KSE site compared with the reference site when juveniles were analyzed separately, and also in kidney when all birds were included in the analysis. The only other site where significant zinc elevations occurred in tissues was the $\mathrm{OK}$ site, where zinc elevation was significant in bone when all birds were included in the analysis. Two birds from the KSE site had liver zinc concentrations in excess of $200 \mathrm{mg} / \mathrm{kg}$, a concentration associated with zinc poisoning in domestic poultry (Puls, 1994).

All tissue lead concentrations, except muscle, were positively correlated with each other, and negatively correlated with blood ALAD activity. Muscle lead was not correlated with lead in brain and pancreas, or blood ALAD activity. The best correlation with blood ALAD activity $(R=-0.677 ; P=0.0001)$ was obtained with bone lead. Proventriculus lead and zinc concentrations were not correlated with tissue concentrations or blood ALAD activity.

\section{DISCUSSION}

Blood ALAD inhibition by $>50 \%$ was found in all tested mine waste-exposed Canada Geese in the Tri-State Mining District. This finding is important because ALAD activity is characteristic of lead exposure in birds, and the degree of inhibition is positively correlated with the 
level of exposure. Blood ALAD inhibition following lead exposure is a consistent finding in birds and can be used as a biomonitoring tool for lead exposure (Vanparys et al., 2008). The inverse exponential relationship we found between ALAD inhibition and blood lead (Fig. 4) is in agreement with patterns observed in previous studics (Vanparys et al., 2008). A reduction in ALAD activity of $>50 \%$ compared to unexposed references is regarded as a reliable indicator of adverse physiologic effects (Vanparys et al., 2008), and this level of ALAD inhibition is accepted as legal evidence of lead poisoning injury in the United States (US Department of the Interior, 1986).

Inhibition of ALAD remained $>50 \%$ whether preflight juveniles or all birds were included in the analysis. If it is assumed that preflight juveniles spend all of their lives close to the collection sites, it indicates that the effect was caused by local exposure. The ALAD activities were not only correlated with blood lead, but also with lead concentrations in other tissucs, except muscle. This has practical implications because blood may not bc available postmortem. Other soft tissues such as liver and kidney, or bone, which is resistant to decay, could be useful indicators of potential ALAD inhibition.

With the exception of bone, lead concentrations in tissues were below published ranges associated with lead poisoning in waterfowl (Puls, 1994). The difference was up to 18 -fold, as demonstrated by the average liver lead of $0.33 \mathrm{mg} / \mathrm{kg}$ at the $\mathrm{KSE}$ site, compared with the reference toxic concentration of $>6 \mathrm{mg} / \mathrm{kg}$. Other available toxic reference concentrations in geese (Puls, 1994) include kidncy ( $>60 \mathrm{mg} / \mathrm{kg}$ ), blood (>1 mg/ $\mathrm{kg}$ ), brain (>3 mg/kg), and bone (>20 $\mathrm{mg} /$ $\mathrm{kg}$ ). This may be explained by the use of a different definition of lead poisoning in the current study, which was $>50 \%$ blood ALAD suppression, compared with behavioral changes, lethargy, anorexia, anemia, and various macroscopic lesions observed at necropsy used to define lead poisoning in the reference data. The importance of this observation is that the legal requirement for defining lead poisoning injury may be reached at tissue concentrations substantially lower than the concentrations associated with visible clinical signs of lead poisoning.

Elevations in tissue zinc compared to the reference site were found only in tissue samples from the KSE site and the OK site (Table 2). Furthermore, two birds from the KSE site had liver zinc concentrations above concentrations accepted as confirmatory for zinc poisoning ( $>200 \mathrm{mg} /$ $\mathrm{kg}$ ) in domestic poultry. Tissue zinc concentrations did not exceed other available toxic ranges for poultry, including kidney (>300 $\mathrm{mg} / \mathrm{kg}$ ), bone $(>1,500 \mathrm{mg} /$ $\mathrm{kg})$, and pancreas $(>1,000 \mathrm{mg} / \mathrm{kg}$; Puls, 1994). Pancreatic lesions associated with zinc poisoning were present in birds from the KSE site. Such lesions were previously described in waterfowl in the study area (Sileo et al., 2003). Pancreatic lesions resembling zine poisoning can occur in poultry with selenium deficiency (Goodwin, 1996), but selenium concentrations (data not shown) were in the normal ranges (Puls, 1994) in birds at all study sites.

Zine is an essential nutrient that plays a role in the functions of more than 300 enzymes (Lindh, 2005). Zine is also very highly regulated, in part through interactions with metallothioneins (Lindh, 2005), and it can be hypothesized that high levels of tissue accumulation are associated with exceptionally high rates of exposure that overcome physiologic control mechanisms. Overall, the co-occurring of elevated zinc with pancreatic lesions was indicative of zine poisoning and is consistent with injury documented in other studies in the Tri-State Mining District (Sileo et al., 2003).

In conchusion, our results confirm that Canada Geese at mine waste-contaminated sites in the Tri-State Mining District consistently suffer adverse health effects

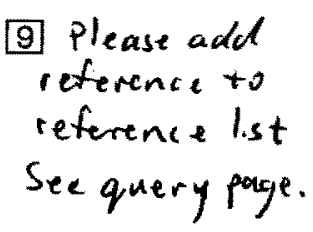


associated with lead exposure, and in some areas, adverse effects due to zinc exposure. These findings support the hypothesis that the health impacts of exposure to mine waste are often not obvious from casual observation of clinical signs and are more widespread than the impacts that can be determined from reports of poisoning cases involving observable signs of disease. The degree of adverse effects is correlated with the degree of exposure. Reducing exposure is, therefore, expected to result in a reduction of adverse health effects in birds. Key questions that remain unanswered include the relative importance of dietary components and how that varies over time, the relative importance of route of exposure and the absorption kinetics of metals from different materials and routes of exposure, the sphere of impact around contaminated sites, and differences in susceptibility between resident and migratory birds.

\section{ACKNOWLEDGMENTS}

We thank Gibran Suleiman of the United States Fish and Wildlife Service for invaluable assistance in planning and sample collection, and Snehal Tawde, Shiva Mohandass, Lori Blevins, Ashley Smit, and Elizabeth Prigge of Kansas State University for assistance with sample collection, processing, and analysis. We also thank Carolyn Cray of the Division of Clinical Pathology, Miller School of Medicine, University of Miami, Florida, USA, for assistance with blood ALAD activity assays. Major funding was provided by the United States Fish and Wildlife Service. Funding assistance was also provided by the National Institutes of Health (NIH T35 RR007064), the MerckMerial Veterinary Scholar Program, and Kansas State University College of Veterinary Medicine.

\section{LITERATURE CITED}

Angelo, R. T., M. S. Chingan, D. L. Chamberlain, A. J. Stanl, S. G. Haslouler, and C. A. Goodrich. 2007. Residual effects of lead and zinc mining on freshwater mussels in the Spring River Rasin (Kansas, Missouri, and Oklahoma, USA), Science of the Total Environment 384: 467-496.

Beyer, W. N., J. Dalgarn, S. Dudding, J. B. French, R. Mateo, J. Miesner, L. Sileo, and J. Spann. 2004. Zine and lead poisoning in wild birds in the Tri-State Minng District (Oklahoma, Kansas, and Missouri). Archives of Environmental Contamination and Toxicology 48: 108-117.

BuKCH, H. B., AND A. L. SIEGEL. 1971. Inproved method for measurement of delta-aminolevulinic acid dehydratase activity of human erythrocytes. Clinical Chemistry 17: 1038-1041.

CH2MHILL. 2005. Third five-year review report for the Tar Creek Superfund Site, Ottawa County, Oklahoma. United States Environmental Protection Agency, Dallas, Texas. 209 pp.

Ceiarlton, B. R., A. J. Bermudez, M. Boulianne, D. A. Halvorson, J. S. Schraden, L. J. Newman, J. E. SANDER, AND P. S. WAKENELL. 2000. Necropsy of the fowl. In Avian discase manual, The American Association of Avian Pathologists, Kemett Square, Penusylvania. pp. 37-38.

Conder, J. M., and R. P. Lanno. 1999. Heavy metal concentrations in mandibles of white-tailed deer living in the Picher Mining District. Bulletin of Environmental Contamination and Toxicology 63: $80-86$.

Conover, M. R., and G. G. Chasko. 1985. Nuisance Canada Goose problems in the eastern United States. Wildlife Society Bulletin 13: 228-233.

Cook, R. S., and D. O. Thainer. 1966. Experimental lead poisoning of Canada Gcese. Journal of Wildlife Management 30: 1-8.

HaYs, K., AND K. MCBEE, 2007. Flow cytometric analysis of red-eared slider turtles (Trachemys scripta) from Tar Creek Superfund Site. Ecotoxicology 16: 353-361.

I INDH, U. 2005. Biological functions of the elements. In Essentials of medical geology, O. Selinus, B. Alloway, J, A Centeno, R. B. Finkelman, R. Fuge, U. Lindh and P. Smedley (eds.). Elsevier Academic Press, Burlington, Massachusetts. pp. 115-160.

Murgueitio, A. M., R. G. Evans, D. Robehts, and T. Moenr. 1996. Prevalence of childhood lead poisoning in a lead mining area. Journal of Environmental Health 58: 12-17,

POPE, L. M. 2005. Assessment of contaminated streambed sediment in the Kansas part of the historie Tri-State Lead and Zinc Mining District, Cherokee County, 2004: U. S. Geological Survey Scientific Investigations Report 2005-5251. US Gcological Survey, Reston, Virginia. $61 \mathrm{pp}$.

Puls, R. 1994. Mineral levels in animal health. 2nd Edition, Sherpa International, Aldergrove, British Columbia, Canada. 356 pp.

Rexnolds, S. K JR., AND L. C. FerRington, JR. 2002 Differential inomhological responses of chironomid larvae to severe heavy metal exposure (Diptera: Chironomidae). Journal of the Kansas Entomological Society 75: 172-184.

Stleo, L., N. W, Beyer, AND R. Mateo. 2003. Pancreatitis in wild zinc-poisoned waterfowl. Avian Pathology 32: 655-660.

US Department OF THE INTERloR. 1986. Natural resource damage assessments. United States 
Code of Federal Regulations, 43 C.F.R., Part 11.62.

Vanpakys, C., T. Danwe, K. Van Campentout, L. Bervoets, W. De Coen, R. Blust, and M. Eens. 2008. Metallothioneins (MTs) and $\delta$-aminolevilinic acid dehydratase (ALAD) as biomarkers of metal pollution in great tits (Panis major) along a pollution gradient. Seience of the Total Environment 401: 184-193.

Wildhabel, M. L., A. L. Alleat, C. J. Scimitt, V. M Tabor, D. Mulhfinn, K. L. Powell, and S. P. Sowa. 2000. Natural and anthropogenic influences on the distribution of the threatened Neosho madtom in a midwestern warmwater stream. Transactions of the American Fisheries Society 129: 243-261.

XIAO, H., AND W. JI. 20007. Relating landscape characteristics to non-point source pollution in unine waste-located watersheds using geospatial techniques. Journal of Environmental Management 82: 111-119.

Yocom, C. F., AND S. W. Harris, 1965. Plumage descriptions and age data for Canada Coose goslings. The Joumal of Wildlife Mamagement 29: $874-877$.

Subnitted for publication 27 January 2010. Accepted 24 Jantary 2011. 
Authors Queries

Journal: Journal of Wildlife Diseases

Paper: jwdi-47-03-45

Title: ADVERSE HEALTH EFFECTS IN CANADA GEESE (BRANTA CANADENSIS) ASSOCIATED WITH WASTE FROM ZINC AND LEAD MINES IN THE TRI-STATE MINING DISTRICT (KANSAS, OKLAHOMA, AND MISSOURI, USA)

Dear Author

During the preparation of your manuscript for publication, the questions listed below have arisen. Please attend to these matters and return this form with your proof. Many thanks for your assistance

\begin{tabular}{|c|c|c|}
\hline $\begin{array}{l}\text { Query } \\
\text { Reference }\end{array}$ & Query & Remarks \\
\hline 1 & $\begin{array}{l}\text { Author: This article has } \\
\text { been lightly edited for } \\
\text { grammar, style, and us- } \\
\text { age. Please compare it } \\
\text { with your original docu- } \\
\text { ment and make correc- } \\
\text { tions on these pages. } \\
\text { Please limit your correc- } \\
\text { tions to substantive } \\
\text { changes that affect mean- } \\
\text { ing. If no change is re- } \\
\text { quired in response to a } \\
\text { question, please write "OK } \\
\text { as set" in the margin. } \\
\text { Copy editor }\end{array}$ & OK as set \\
\hline 2 & $\begin{array}{l}\text { Author: Please note that } \\
\text { journal style requires Sl } \\
\text { units. Please convert } \\
2,500 \text { square miles to area } \\
\text { in } \mathrm{km} 2 \text {. Copy editor }\end{array}$ & $6,500 \mathrm{~km}^{2}$ \\
\hline 3 & $\begin{array}{l}\text { Author: Please define ab- } \\
\text { breviations used in the } \\
\text { Fig. } 1 \text { caption. Copy editor }\end{array}$ & $\begin{array}{l}\text { What appeavs to be } \\
\text { abbreviatichs are } \\
\text { study site idenxification } \\
\text { codes. }\end{array}$ \\
\hline 4 & $\begin{array}{l}\text { Author: Please verify "25- } \\
\text { gauge" in place of " } 25-g \text { ". } \\
\text { Copy editor }\end{array}$ & Correct \\
\hline
\end{tabular}




\begin{tabular}{|c|c|c|}
\hline 5 & $\begin{array}{l}\text { Author: Please verify that } \\
\text { the sentence beginning "A } \\
\text { unit of ALAD" conveys the } \\
\text { intended meaning. Copy } \\
\text { editor }\end{array}$ & Correct \\
\hline 6 & $\begin{array}{l}\text { Author: Please define ab- } \\
\text { breviations in footnote "a" } \\
\text { of Table } 1 . \text { Copy editor }\end{array}$ & $\begin{array}{l}\text { As for figd they are } \\
\text { site ID codes see query } 3\end{array}$ \\
\hline 7 & $\begin{array}{l}\text { Author: Table } 2 \text { has been } \\
\text { reformatted per journal } \\
\text { style. Copy editor }\end{array}$ & OK \\
\hline 8 & $\begin{array}{l}\text { Author: In column "Mus- } \\
\text { cle" and the sites under } \\
\text { row "Lead", the super- } \\
\text { scripts a and b have been } \\
\text { removed. OK? Copy edi- } \\
\text { tor }\end{array}$ & $O K$ \\
\hline 9 & $\begin{array}{l}\text { Author: Please note that } \\
\text { Goodwin (1996) does not } \\
\text { have a matching refer- } \\
\text { ence. Copy editor }\end{array}$ & 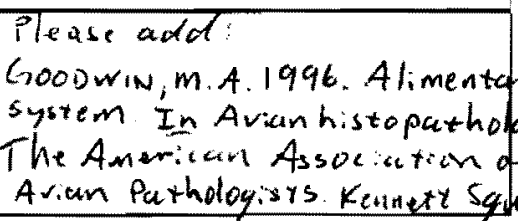 \\
\hline
\end{tabular}

EDITORIAL STAFF: Query markers appear in boxes in the margins as a question mark followed by a number. Please respond to each query in the margin of the corresponding proof page. Comment markers are suggested corrections that will also appear in the margin, but as a " $\mathrm{C}$ " followed by a number. If you wish to implement the suggested correction, please transfer the correction to the margin and text of the corresponding proof page.

C1. In the Reynolds reference, insert punctuation so this reads Reynolds, S. K., Jr., 